удк 551.4.08

Pamela Nolakana, Abdi Siad, Henok Solomon Earth Science Department, Science Faculty, University of the Western Cape, Private Bag X 17, Modderdam Road, Bellville, 7535, Cape Town, South Africa

\title{
EVALUATION OF GROUNDWATER SUITABILITY FOR DOMESTIC AND IRRIGATIONAL PURPOSES IN NEWCASTLE, KWAZULU-NATAL, SOUTH AFRICA
}

(Рекомендовано членом редакційної колееії д-ром геол. наук, проф. О.Є. Кошляковим)

The study was conducted in Newcastle, in the KwaZulu-Natal province of South Africa. In order to evaluate the quality of groundwater in study area, 31 samples were collected. The samples were analysed for Magnesium (Mg2+), Calcium (Ca2+), Sodium (Na+), Potassium (K+), Chloride (Cl-), Sulfate (SO42-), Bicarbonate (HCO3-), Nitrate (NO3-), Fluoride (F-) (pH, TDS and Ec. The South African Quality Water Guidelines (SAQWG) and the World Health Organization (WHO) water standards were used as the basis of evaluating the suitability of groundwater for drinking purposes. Electrical Conductivity (EC), Sodium Percent (Na \%), Sodium Adsorption Ratio (SAR), Residual Sodium Carbonate (RSC), Kelly's Ratio (KR), Magnesium Ratio (MR) and Permeability Index (PI) were used to evaluate suitability for irrigation. The spatial distribution of the results was presented using ArcGIS. The groundwater was found to be generally alkaline, soft to hard and fresh to brackish in nature. The order of abundance of major ions in the groundwater, based on their mean values is as follows: $\mathrm{Na}+>\mathrm{Ca} 2+>\mathrm{Mg} 2+>\mathrm{K}+$ and $\mathrm{HCO} 3->\mathrm{SO} 42->\mathrm{Cl}->\mathrm{NO} 3-$.

Keywords: Groundwater, SAQWG, suitability, domestic, irrigation.

Introduction. Groundwater is one of the most valuable natural resources on earth and it forms an important part of the total water resources of South Africa. For this reason, this resource should be monitored and controlled on a regular basis. The aim of this study was to assess the groundwater suitability for domestic and irrigation purposes. The study was conducted in Newcastle, in the KwaZulu-Natal province of South Africa (Fig. 1). For the purpose of this study 31 samples were collected from 31 boreholes in and around the town of Newcastle. The samples were analysed for Magnesium $(\mathrm{Mg} 2+)$, Calcium $(\mathrm{Ca} 2+)$, Sodium $(\mathrm{Na}+)$, Potassium $(\mathrm{K}+)$, Chloride $(\mathrm{Cl}-)$, Sulfate (SO42-), Bicarbonate (HCO3-), Nitrate (NO3-), Fluoride (F-) (pH, TDS and Ec. The SAQWG [5] and the WHO [18] water standards were used as the basis of evaluating the suitability of groundwater for drinking purposes. For irrigation, Electrical Conductivity (EC),
Sodium Percent ( $\mathrm{Na} \%$ ), Sodium Adsorption Ratio (SAR), Residual Sodium Carbonate (RSC), Kelly's Ratio (KR), Magnesium Ratio (MR) and Permeability Index (PI) were used to evaluate suitability. Lastly, the spatial distribution of the results was presented using ArcGIS.

The geology in Newcastle mainly consists of rocks from the Karoo Super Group. Deposition of these sediments began late Carboniferous and continued to accumulate until Early Jurassic when it was interrupted and eventually brought to a close by widespread flood basaltic volcanism [2]. The rocks that outcrop in the study area belong to Beaufort Group (consisting of mud and sandstone), Karoo Dolerite and the Volksrust Formation (silty shale and sandstone) and Vryheid Formation (consist primarily of sandstone and several coal seams) of the Ecca Group (Fig. 2). Of these, however, the Vryheid formation is the most dominant in the study area.

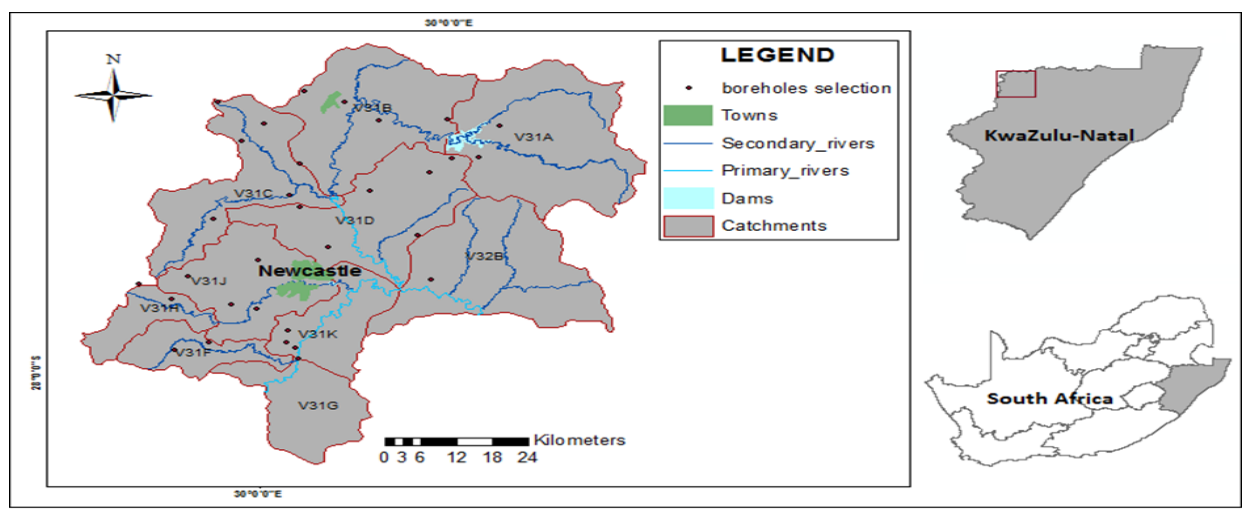

Fig. 1. Study area and location of boreholes

The indicated aquifer types in the Newcastle area are intergranular and fractured aquifers with an extremely low to medium development potential. The underlying geology is mostly arenaceous rock of the Ecca Formation SAQWG [4]. The host geology of the area consists of consolidated sediments of the Karoo Super Group and consists mainly of sandstone, shale and coal beds of the Vryheid Formation. Most of the groundwater flow will be along the fracture zones that occur in relatively competent host rock.

The groundwater geochemistry of the study area is dominated the following water types $\mathrm{Ca}-\mathrm{Mg}-\mathrm{HCO} 3, \mathrm{Na}-$ $\mathrm{HCO} 3$, Ca-Na-SO4-HCO3 (Mixed water type) and $\mathrm{Na}-\mathrm{Cl}$ [12]. The Ca-Mg-HCO3 facies mainly found in 18 of the boreholes in the study area, these boreholes are mainly distributed in the Vryheid $\mathrm{Fm}$ and in the contact zones between the Karoo dolerite with the Volksrust Fm and with the Vryheid Fm. This type of water is mainly attributed to the dissolution of carbonate minerals and characterised by combined concentrations of $\mathrm{Ca} 2+, \mathrm{Mg} 2+$ and $\mathrm{HCO} 3-$ that exceeds $50 \%$ of the total dissolved constituent load in $\mathrm{meq} / \mathrm{L}$. Na-HCO 3 water generally indicates the occurrence of ion exchange processes. It could also be attributed to silicate weathering, because of the high levels of $\mathrm{Na}+$ and $\mathrm{HCO} 3-$ which are end products of Albite weathering. Ca$\mathrm{Na}-\mathrm{SO} 4-\mathrm{HCO} 3$ water is a product of mixing of water types attributed to the combined influence of silicate weathering, calcite dissolution, ion exchange processes and gypsum dissolution. $\mathrm{Na}-\mathrm{Cl}$ is characterised by high levels of $\mathrm{Na}+$ and $\mathrm{Cl}$ - ions, which could be attributed to halite dissolution and ion exchange processes. 


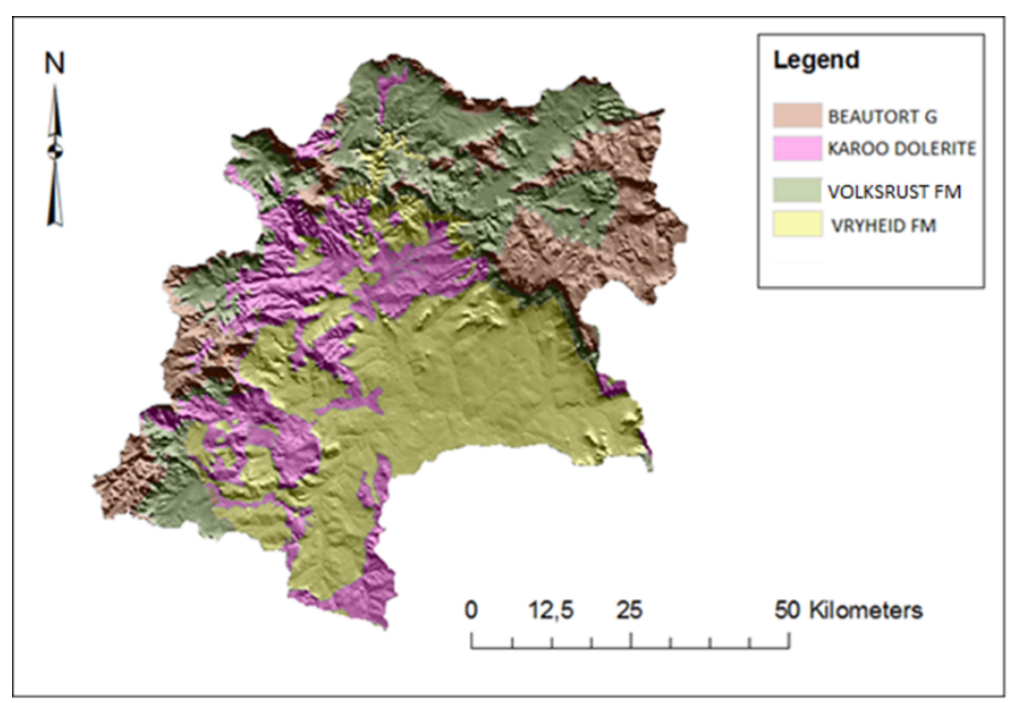

Fig. 2. Local geology of the study area

Methods. The data was supplied by the Department of Water Affairs (DWA). For the purposes of this study 31 samples were used, which were collected from 31 different wells. The wells are located in 10 Quaternary catchments areas in Newcastle. The samples were analyzed for the following: Magnesium $(\mathrm{Mg} 2+)$, Calcium $(\mathrm{Ca} 2+)$, Sodium $(\mathrm{Na}+)$, Potassium $(\mathrm{K}+)$, Chloride $(\mathrm{Cl}-)$, Sulfate (SO42-), Bicarbonate (HCO3-), Nitrate (NO3-), Fluoride ( $\mathrm{F}-\mathrm{)}, \mathrm{pH}$, TDS and EC.

Data Analysis. Univariate Analysis. Physicochemical variables/parameters of the groundwater samples were analysed using Microsoft Excel Spread sheet. This software was utilized for descriptive statistical analysis of the groundwater samples to produce different tables which contain the maximum, minimum, mean and standard deviation. Descriptive statistics were then used for classification and standard comparison of the groundwater.

Standard Water Comparison. Water guidelines/standards are developed to ensure that water quality remains fit for human consumption and use. These standards are used as guidelines to regulate the concentration of chemical constituents in water to ensure that the level is not harmful to human health [20]. The groundwater geochemistry data from the Newcastle area was compared to water standards to assess whether the quality of the groundwater in the area meets the criteria. The guidelines used for classification and evaluations of the groundwater in the study area are:

For drinking:

Domestic water use SAQWG [5];

Guidelines for drinking water quality WHO [18];

Water classification based on TDS [3];

Water classification based on TDS [8];

Water classification based on $\mathrm{TH}$ [17];

Salinity hazard classification based on EC [18].

For irrigation

Electrical Conductivity (Ec);

Sodium Adsorption Ratio (SAR), which is computed using the formula:

$$
\text { SAR }=\frac{\mathrm{N}^{+}}{\sqrt{\left(\mathrm{Ca}^{2+}+\mathrm{Ma}^{2+}\right) 2}}
$$

with all concentrations expressed in meq//;

Kelly's ratio $(\mathrm{KR})$ :

$\mathrm{KR}=\frac{\mathrm{Na}^{+}}{\mathrm{Ca}^{2+}+\mathrm{Mg}^{2+}}$

concentrations expressed in meq/l;

Sodium Percentage ( $\mathrm{Na} \%)$ :

$$
\mathrm{Na} \%=\frac{\left(\mathrm{Na}^{+}+\mathrm{k}^{+}\right) \times 100}{\left(\mathrm{Ca}^{2+}+\mathrm{Mg}^{2+}+\mathrm{Na}^{+}+\mathrm{K}^{+}\right)}
$$

concentrations expressed in meq/l;

Residual Sodium Carbonate (RSC):

$\mathrm{RSC}=(\mathrm{HCO} 3-+\mathrm{CO} 3-)-(\mathrm{Ca} 2++\mathrm{Mg} 2+)$

concentrations expressed in meq/l;

Magnesium Hazard (MR):

$\mathrm{MR}=\frac{\mathrm{Mg}^{2+} \times 100}{\mathrm{Mg}^{2+}+\mathrm{Ca}^{2+}}$

concentrations expressed in meq//;

Permeability Index (PI):

$\mathrm{PI}=\frac{\left(\mathrm{Na}^{+}+\sqrt{\mathrm{HCO}_{3}}{ }^{-}\right) \times 100}{\mathrm{Ca}^{2+}+\mathrm{Mg}^{2+}+\mathrm{Na}^{+}}$

concentrations expressed in meq/l.

RESULTS AND DISCUSION. This Chapter will present results and discussion based on the groundwater chemistry and the methods that were used to further classify and characterise the hydrochemical processes responsible for the quality of the water.

Evaluation for Suitability. Evaluation for Drinking Purposes. Chemically, water used for drinking should be soft, low in dissolved salts and free from toxic constituents [16]. The standards for drinking water by SAQWG [5], (Table 1) and WHO [18], (Table 1), were used as the basis of evaluating the suitability of groundwater for drinking purposes.

Table 1. Descriptive statistics of groundwater chemistry compared with SAWQG (DWAF, 1996) and WHO Drinking Water Standards [18]

\begin{tabular}{|l|c|c|c|c|c|c|c|c|}
\hline Variable & Min & Max & Mean & $\begin{array}{c}\text { Standar } \\
\text { d Dev. }\end{array}$ & $\begin{array}{c}\text { SAWQG } \\
\text { Target } \\
\text { Range }\end{array}$ & $\begin{array}{c}\text { Number of samples } \\
\text { exceeding the SAWQG } \\
\text { Target Water range }\end{array}$ & $\begin{array}{c}\text { WHO Water } \\
\text { Standards } \\
\text { (mg/l) }\end{array}$ & $\begin{array}{c}\text { Number of samples } \\
\text { exceeding WHO } \\
\text { recommended limit }\end{array}$ \\
\hline pH & 6.65 & 10.09 & 7.79 & 0.52 & $6.0-9.0$ & 1 & - & \\
\hline EC & 4.9 & 186 & 41.53 & 37.49 & $0-70$ & 4 & - & \\
\hline TDS & 29 & 1091.00 & 324.78 & 253.51 & $0-450$ & 5 & 1000 & 2 \\
\hline TH & 3.31 & 504.23 & 103.29 & 104.07 & - & - & - & \\
\hline${ }^{*} \mathrm{Ca} 2+$ & 0.5 & 123.6 & 24.26 & 25.71 & $0-32$ & 8 & 250 & 0 \\
\hline
\end{tabular}


End of table 1

\begin{tabular}{|l|c|c|c|c|c|c|c|c|}
\hline Variable & Min & Max & Mean & $\begin{array}{c}\text { Standar } \\
\text { d Dev. }\end{array}$ & $\begin{array}{c}\text { SAWQG } \\
\text { Target } \\
\text { Range }\end{array}$ & $\begin{array}{c}\text { Number of samples } \\
\text { exceeding the SAWQG } \\
\text { Target Water range }\end{array}$ & $\begin{array}{c}\text { WHO Water } \\
\text { Standards } \\
\text { (mg/l) }\end{array}$ & $\begin{array}{c}\text { Number of samples } \\
\text { exceeding WHO } \\
\text { recommended limit }\end{array}$ \\
\hline${ }^{*} \mathrm{Mg} 2+$ & 0.5 & 47.5 & 10.37 & 11.08 & $0-30$ & 2 & 100 & 0 \\
\hline $\mathrm{Na}+$ & 2.7 & 350.5 & 49.11 & 68.55 & $0-100$ & 4 & 200 & 1 \\
\hline${ }^{*} \mathrm{~K}+$ & 0.15 & 4.84 & 1.55 & 1.25 & $0-50$ & 0 & 12 & 0 \\
\hline $\mathrm{Cl}-$ & 1.5 & 430.70 & 23.10 & 77.03 & $0-100$ & 2 & 250 & 1 \\
\hline $\mathrm{F}-$ & 0.11 & 1.91 & 0.47 & 0.42 & $0-1.1$ & 2 & 1.5 & \\
\hline $\mathrm{HCO}-$ & 13.3 & 355.3 & 146.66 & 77.10 & - & 1 & - & 2 \\
\hline SO4- & 2 & 525.7 & 33.67 & 97.30 & $0-200$ & 0 & 250 & \\
\hline NO3- & 0.02 & 4.78 & 0.64 & 1.16 & $0-6$ & 0 & 50 & 1 \\
\hline
\end{tabular}

$\mathrm{N}=31$. All values are in $\mathrm{mg} / \mathrm{L}$ except $\mathrm{EC}$, in $\mathrm{mS} / \mathrm{m}$ and $\mathrm{pH}$ (no units); - no standard available, *No WHO guideline value assigned, values in the table represent taste threshold values.

The $\mathrm{pH}$ of the water in the study area ranges between 6.65 and 10.09 with an average of 7.79 , only 1 sample falls outside this range. The $\mathrm{pH}$ of water is controlled by dissolved carbonates and higher $\mathrm{pH}$ reflects high presence of acid neutralizing constituents [1]. The $\mathrm{pH}$ of the study area can be classified as being within the target range for domestic use and is indicative of the alkaline nature of the groundwater in the area. Ec ranges from 4.9 to $186 \mathrm{mS} / \mathrm{m}$ with a mean value of $41.53 \mathrm{mS} / \mathrm{m}, 37$ of the groundwater samples fall within the target range $(0-70 \mathrm{mS} / \mathrm{m})$ with only 4 of the samples falling outside this range. The high of Ec in these boreholes is mainly due to the high levels of $\mathrm{Na}+$ and $\mathrm{Cl}-$ and it is known to cause gastrointestinal irritation in human beings after long term use [16]. The concentration of TDS in the groundwater varies from 29 to $1091 \mathrm{mg} / \mathrm{l}$ with an average of $324.77 \mathrm{mg} / \mathrm{l}$. Most of the samples fall within the desirable range with only 5 out of 31 samples falling outside this range as per SAWQG [5] and 2 as per WHO [18] standards. Figure 3 shows the two areas that show an increase in TDS concentration, boreholes 13 and 31 are situated on the Vryheid Fm. High TDS values in these two boreholes is mainly related to high levels of $\mathrm{Na}, \mathrm{Cl}-$ and SO42- ions. The order of abundance of major ions in the groundwater, based on their mean values is as follows: $\mathrm{Na}>\mathrm{Ca}>\mathrm{Mg}>\mathrm{K}$ and $\mathrm{HCO} 3>\mathrm{SO} 4>\mathrm{Cl}>\mathrm{NO} 3$. The desirable range for $\mathrm{Na}+$ according to the SAWQG [5] is $\leq 100 \mathrm{mg} / \mathrm{l}$ and $\leq 200$ according to [18] standards. $\mathrm{Na}+$ in the study area varies from 2.7 to $350.5 \mathrm{mg} / \mathrm{l}$ with an average of $49.11 \mathrm{mg} / \mathrm{l}$, most of the samples fall within the target range, 4 samples fall out of the desirable range as per SAWQG [5] and 1 as per WHO [18] standards. Figure 4, a shows that this sample comes from borehole 13, situated in the Vryheid Formation, the source of high $\mathrm{Na}+$ ions in this borehole might be from silicate weathering. Borehole 13 also shows high levels of $\mathrm{Cl}-$, this might also be indicative of halite dissolution as another source of these ions in the area.

$\mathrm{Ca} 2+$ in the study area ranges between 0.5 and 123.6 $\mathrm{mg} / \mathrm{l}$ with an average of $24.26 \mathrm{mg} / \mathrm{l}$ and the SAWQG [5] target range is $<32 \mathrm{mg} / \mathrm{l}$. 23 of the samples fall within the target range while 8 are outside this range. The concentration of $\mathrm{Mg} 2+$ found in the samples of the study area ranges between 0.5 to $47.5 \mathrm{mg} / \mathrm{l}$ with average value of $10.37 \mathrm{mg} / \mathrm{l}$. The target range according to the SAWQG [5] is $<30 \mathrm{mg} / \mathrm{l}, 29$ of the samples in the area fall within the target range. Calcium and Magnesium do not have WHO guideline value assigned to them because they are not of concern in values found in water [18]. But all values do fall into the taste threshold values as per [18] (Fig. 5, a, b).

HCO3-, which is the most dominant anion in the study area, has concentrations that vary from 13.3 to $355.3 \mathrm{mg} / \mathrm{l}$ and an average of $146.66 \mathrm{mg} / \mathrm{l}$. The HCO3- levels in water are directly related to the alkalinity of the water [7] and the high levels of $\mathrm{HCO}^{-}$- indicate that the groundwater is alkaline in nature meaning that the groundwater has a high capacity to neutralize acid forming reactions. The target range for $\mathrm{Cl}$ - according to the SAWQG [5] is $0-100 \mathrm{mg} / \mathrm{l}$ and $\leq 250 \mathrm{mg} / \mathrm{l}$ according to [18] standards, the concentration in the study area ranges from 1.5 to 430.7 $\mathrm{mg} / \mathrm{l}$ with an average of $23.10 \mathrm{mg} / \mathrm{l}$. Only 1 sample exceeds both the SAWQG [5] and WHO [18] target range for $\mathrm{Cl}-$-, figure 6 , a shows that this sample is situated on the Vryheid Fm in borehole 13. The high levels of $\mathrm{Cl}$ - in this borehole correlate with high levels of $\mathrm{Na}+$ and this could be an indicative of halite dissolution as source of $\mathrm{Cl}$ - lons in this borehole. SO4- levels range from 2 to $525.7 \mathrm{mg} / \mathrm{l}$ with an average of $33.67 \mathrm{mg} / \mathrm{l}$ and 1 of sample falls outside the target range as per SAWQG [5] and WHO [18] standards; this sample is situated in borehole 31 (Fig. 6, b). The source of SO42- in this borehole might be due to gypsum dissolution, because this borehole also shows high concentration of $\mathrm{Ca} 2+$. The concentration of $\mathrm{F}$ - in the study area ranges between $0.11-1.91 \mathrm{mg} / \mathrm{l}$ with an average of 0.42 and 2 of the groundwater samples fall outside the desirable range as per SAWQG [5] and WHO [18] standards.

TDS is one of the most important parameters used to investigate water suitability for drinking. [3] and [8] devised classification methods to classify water suitability according to TDS levels.

According to [3] groundwater classification based on TDS (Table 2), $83.87 \%$ of the groundwater in the study area is desirable for drinking and $9.68 \%$ of the groundwater samples indicate permissible TDS values. Furthermore, $6.45 \%$ of the groundwater samples in the study area are useful for irrigation purposes. None of the samples fall into the unfit for drinking classification. The high levels of TDS in this water are mainly due to high levels of $\mathrm{Na}+, \mathrm{Cl}-$ and SO42- ions these boreholes. Based on these classifications the water is suitable for both drinking and irrigation.

Table 2. Davis and DeWiest (1966) Classification based on TDS

\begin{tabular}{|c|c|c|c|}
\hline TDS(mg/l) & Classification & Number of samples & Percentage \\
\hline$<500$ & Desirable for drinking water & 26 & $83.87 \%$ \\
\hline $500-1000$ & Permissible for drinking water & 3 & $9.68 \%$ \\
\hline $1000-3000$ & Useful for irrigation water & 2 & $6.45 \%$ \\
\hline$>3000$ & Unfit for drinking and irrigation & 0 & 0 \\
\hline
\end{tabular}

Classification based on TDS according to [8] (Table 3) shows that $93.54 \%$ of the groundwater samples are considered fresh water while $6.45 \%$ is classified as brackish water type. None of the groundwater samples fall into the saline and brine water type. 
Hardness of water limits its use for industrial purposes because hard water causes scaling of pots, boilers and irrigation pipes and it may cause health problems to humans, such as kidney failure WHO [20]. Classification of water based on $\mathrm{TH}$ by [17] (table 4) indicates that water with $\mathrm{TH}$ lower than $75 \mathrm{mg} / \mathrm{l}$ is considered soft and higher than $300 \mathrm{mg} / \mathrm{l}$ is considered very hard. $54.84 \%$ of the groundwater samples fall into the soft category, $19.35 \%$ moderately high classification, $22.58 \%$ hard and $3.23 \%$ fall within the very hard classification.
Figure 7 below illustrates the spatial distribution of concentration of $\mathrm{TH}$ with consideration to the [17] classification. Concentration between 150 and 300 (hard category are found in boreholes $30,24,14,5,3,16$, and 19 and concentration of $>300$ which belong to the hard category are found in borehole 31 . The reason for high $\mathrm{TH}$ in these boreholes especially 31 is due to the high concentration of $\mathrm{Ca} 2+$ and $\mathrm{Mg} 2+$, which could be due to silicate weathering, carbonate weathering and gypsum dissolution in the Vryheid and Volkrust Formation.

Table 3. Freeze and Cherry (1979) classification based on TDS

\begin{tabular}{|c|c|c|c|}
\hline TDS (mg/l) & Classification & Number of samples & Percentage \\
\hline$<1000$ & Fresh water & 29 & $93.54 \%$ \\
\hline $1000-10000$ & Brackish water type & 2 & $6.45 \%$ \\
\hline $10000-100000$ & Saline water type & 0 & 0 \\
\hline$>100000$ & Brine water type & 0 & 0 \\
\hline Total & & 31 & 100 \\
\hline
\end{tabular}

Table 4. Sawyer and McCarthy (1967) classification based on TH

\begin{tabular}{|c|c|c|c|}
\hline TH & Classification & Number of samples & Percentage \\
\hline$<75$ & Soft & 17 & $54.84 \%$ \\
\hline $75-150$ & Moderately high & 6 & $19.35 \%$ \\
\hline $150-300$ & Hard & 7 & $22.58 \%$ \\
\hline$>300$ & Very Hard & 1 & $3.23 \%$ \\
\hline
\end{tabular}
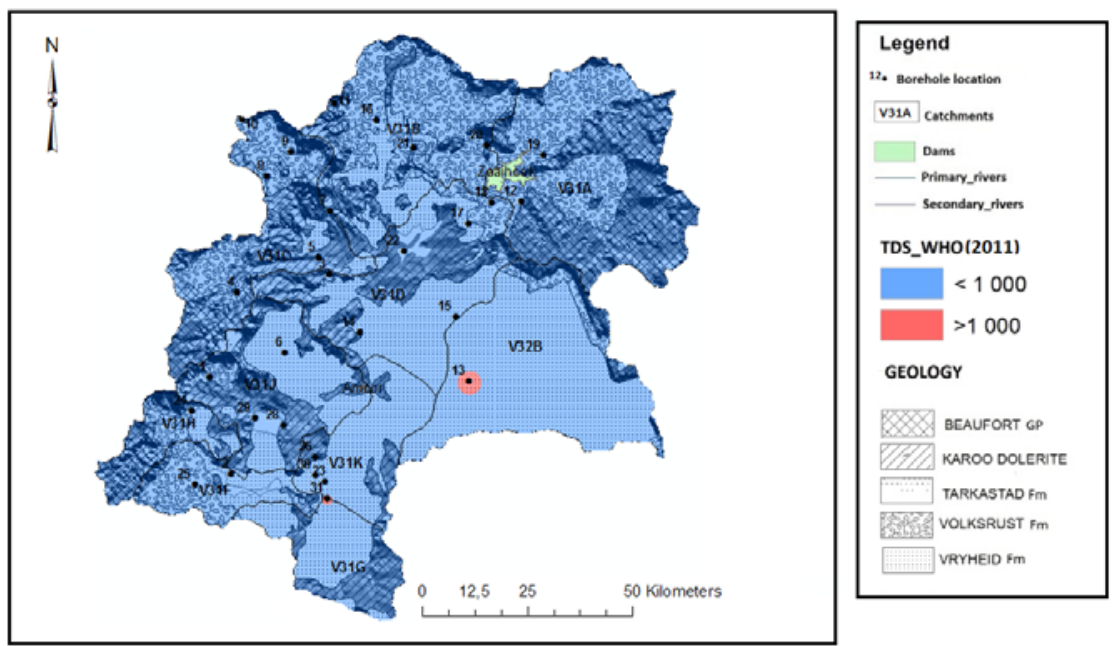

Fig.3. TDS concentration classification of the groundwater samples based on WHO [19] drinking water Guidelines

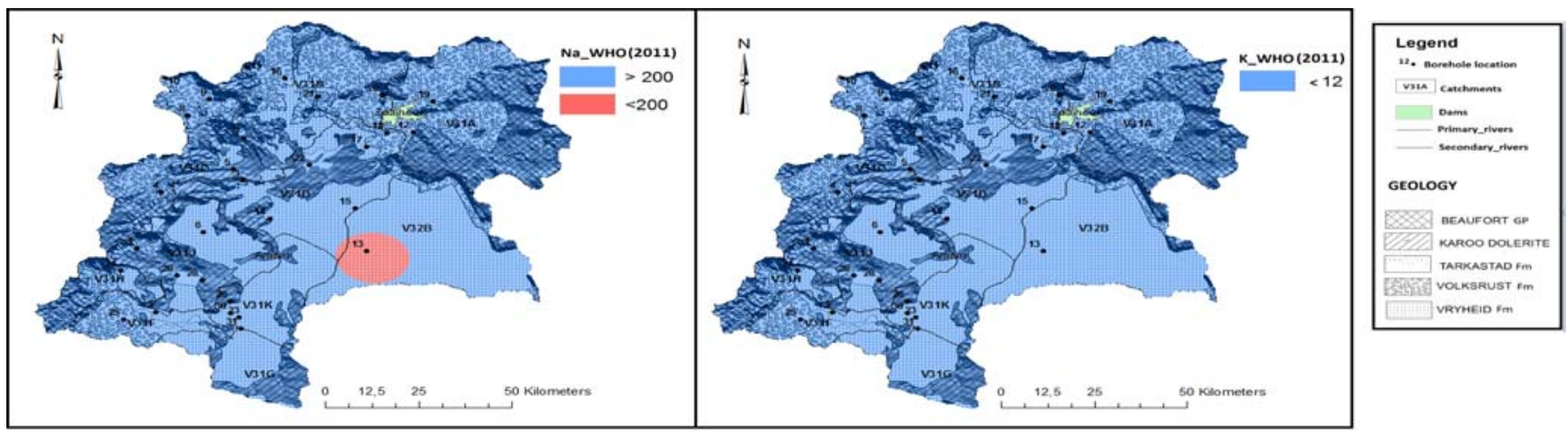

Fig. 4. Cations (a) $\mathrm{Na}+$ and (b) $\mathrm{K}+$ concentration classification of the groundwater samples based on [18] drinking water guidelines 

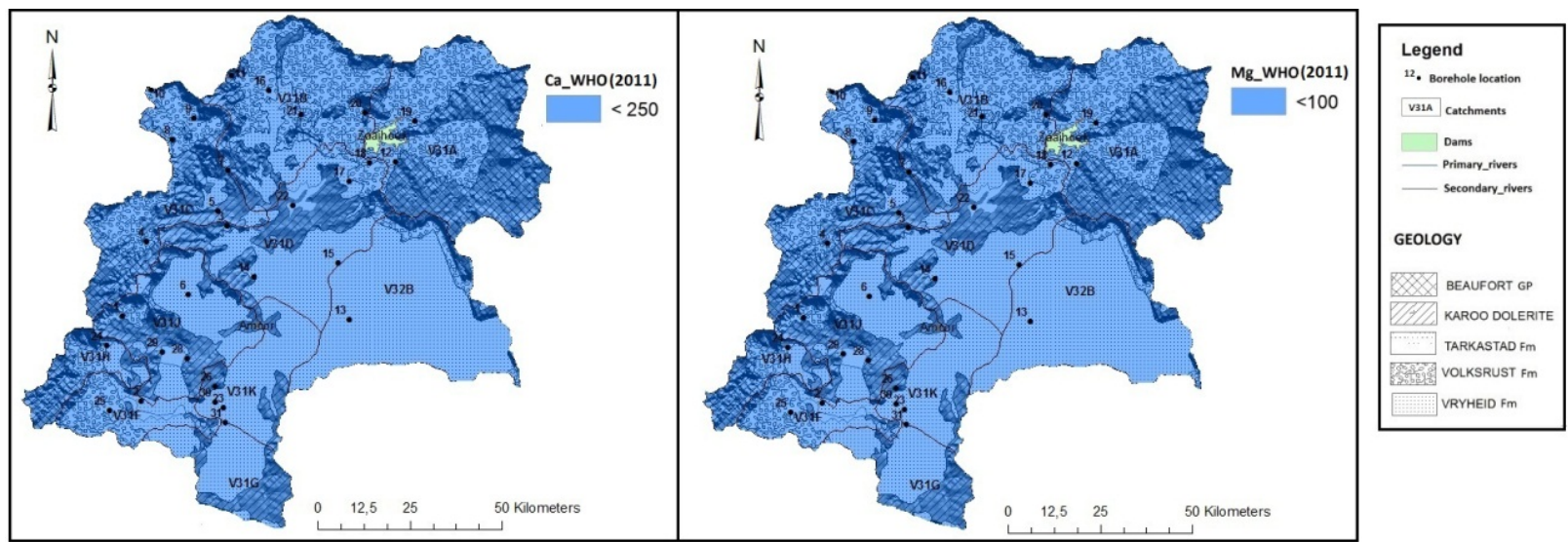

a

b

Fig. 5. Cations (a) Ca2+, (b) Mg2+ concentration classification of the groundwater samples based on [18] drinking water guideline

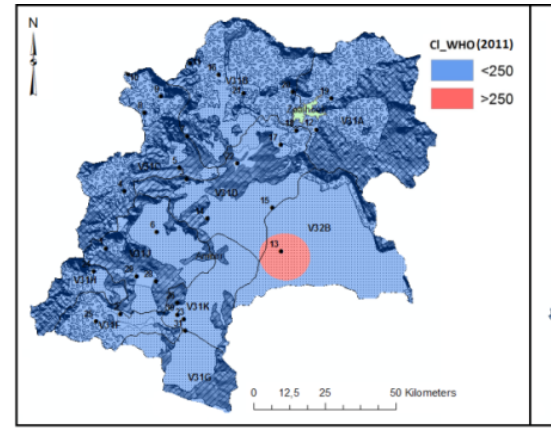

a

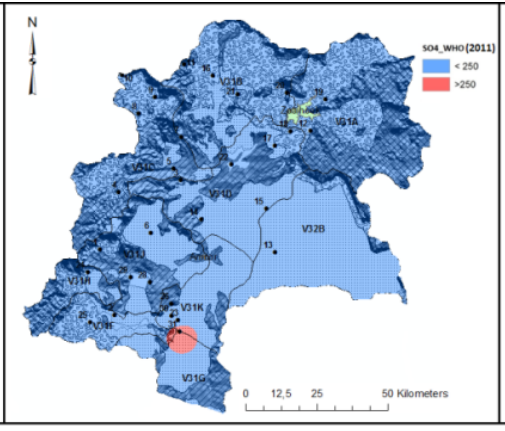

b

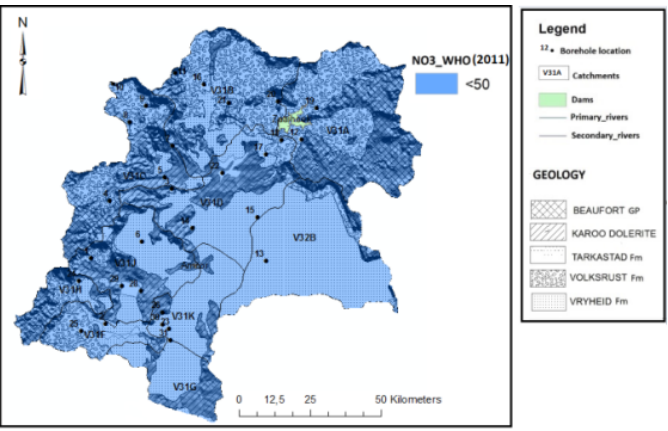

Fig. 6. Anions (a) Cl- , (b) SO42- and (c) NO3-concentration classification of the groundwater samples based on WHO [19] drinking water guidelines
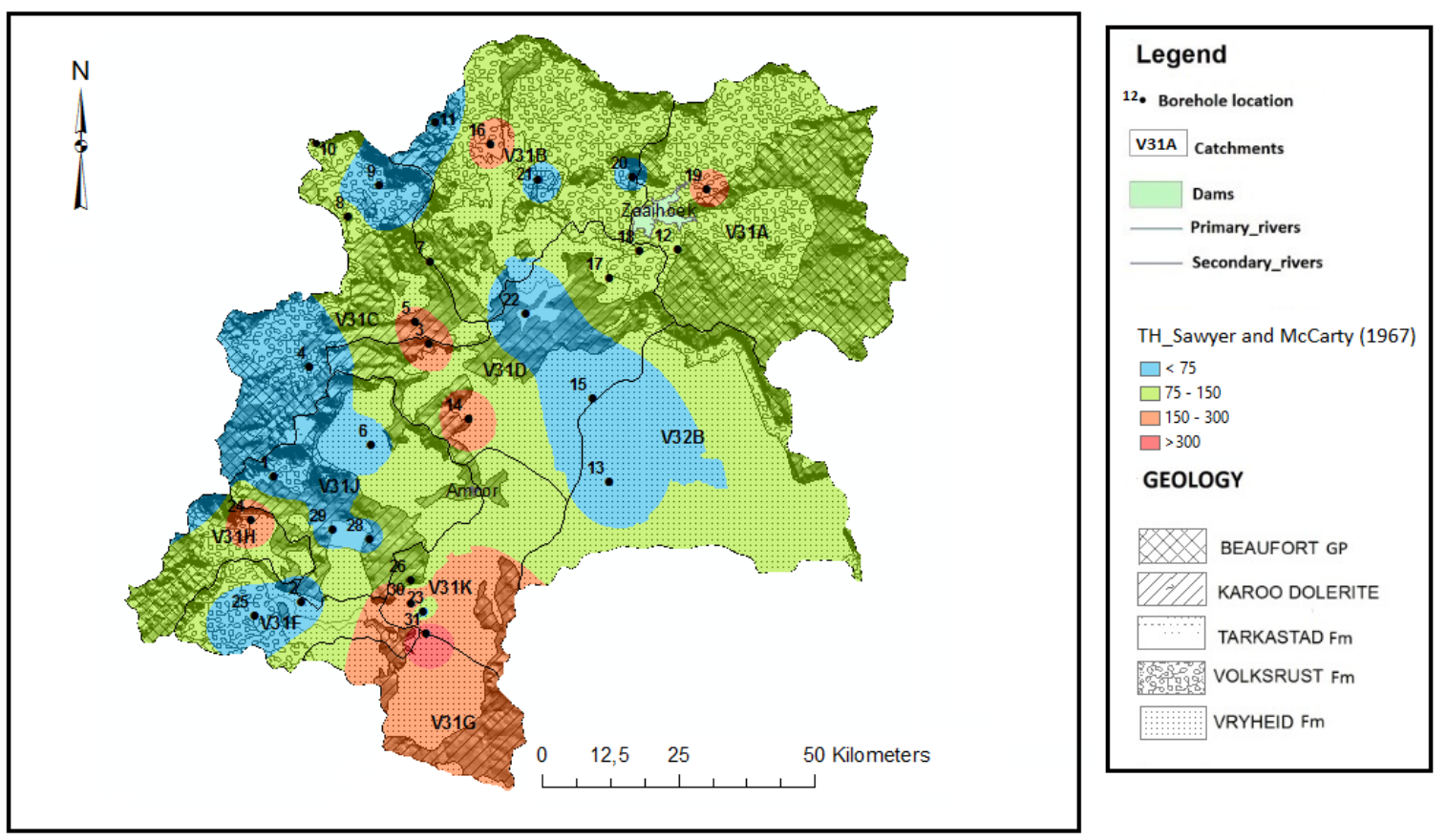

Fig. 7. TH concentration classification of the groundwater samples based [18] classification 
Parameters used to assess the quality of water for irrigation include:

total salt concentration measured by EC (salinity hazard);

the relative proportion of sodium which indicate the sodium hazard, which are:

the Sodium percent;

Sodium Absorption Ratio (SAR);

Residual Sodium Carbonate ( RSC);

Kelly's ratio.

Permeability index.

Magnesium hazard
Water with inferior quality for irrigation could lead to reduced crop yield [16].

Salinity Hazard. The salinity hazard increases the osmotic pressure of the soil water and restricts the plant roots from absorbing water, the results in a physiological drought condition [10]. Table 5 below shows the classification of water based on EC [18]. According to this classification all the groundwater samples fall in the low salinity hazard classification below $250 \mathrm{mS} / \mathrm{m}$. This shows that, with respect to salinity hazard the groundwater in the study area is suitable for irrigation.

Table 5. Classification of water based on EC (US salinity Laboratory, 1954)

\begin{tabular}{|c|c|c|c|}
\hline Salinity Hazard & $\mathbf{E C}(\mathbf{m S} / \mathbf{m})$ & No. Of samples & $\%$ \\
\hline Low & $<250$ & 31 & 100 \\
\hline Medium & $250-750$ & 0 & 0 \\
\hline High & $750-2250$ & 0 & 0 \\
\hline Very high & $>2250$ & 0 & 0 \\
\hline Total & & 31 & 100 \\
\hline
\end{tabular}

Sodium harzard. The sodium hazard results from accumulation of sodium in an excessive amount which causes the physical structure of the soil to breakdown. When calcium and magnesium are replaced by sodium adsorbed on clays, the results is the dispersal of the soil particles. Consequently, the soil becomes hard and compact when dry and increasingly impervious to water resulting in plant roots not getting enough water [10]. For this reason, the sodium in water is an important parameter when determining suitability of the water for irrigation.

Sodium Adsorption Ratio. The sodium adsorption ratio (SAR) is an index of the potential of a given irrigation water to induce sodic soil conditions. Sodicity in irrigation water is due to high concentration of $\mathrm{Na}+$ relative to $\mathrm{Ca} 2+$ and $\mathrm{Mg} 2+$. SAR is computed from the relative measures of these cations SAQWG [5]. Water with SAR $\leq 6$ is more desirable for irrigation and water with $S A R \geq 9$ may cause the soil structure to deteriorate resulting in slower water infiltration and residual soil reduced air movement [14].

The SAR is computed using the formula [9]:

$$
\mathrm{SAR}=\frac{\mathrm{Na}^{+}}{\sqrt{\left(\mathrm{Ca}^{2+}+\mathrm{Mg}^{2+}\right) \times \frac{1}{2}}}
$$

Where, the ion concentrations are expressed in meq/l

The minimum and maximum values of SAR for groundwater samples in the area were 0.22 and 21.88 respectively with an average value of 3.75 and standard dev. value is $5.91 .77 .4 \%$ of the groundwater samples have SAR less than 6 while $22.58 \%$ have SAR greater than 9 . Majority of the samples have low SAR meaning they have more $\mathrm{Ca} 2+$ and $\mathrm{Mg} 2+$ relative to $\mathrm{Na}+$, which indicates that the capacity of the water to induce sodic conditions in the soil is low and are suitable for irrigation. Whereas, $22.58 \%$ of the samples have SAR greater than 9 meaning they have more $\mathrm{Na}+$ than $\mathrm{Ca} 2+$ and $\mathrm{Mg} 2+$, resulting in high capacity of the water to cause soil sodicity and therefore unsuitable for irrigation.

Figure 8 illustrates classification of groundwater in relation to salinity hazard (Ec) and sodium hazard (SAR) by the [18]. According to the classification $87,1 \%$ of the samples fall in the C1S1 (low salinity with low sodium) category which is good for irrigation, while $3.23 \%$ falls into the C1S2 (low salinity with medium sodium) category and $9.68 \%$ fall into the C1S3 (low salinity with high sodium). The water samples that fall into the C1S3 class have higher sodium content meaning they could lead to alkaline soils [15]. Alkali soils have very poor structure and low infiltration capacity.

Percentage of Sodium. Percentage of $\mathrm{Na}+$ is widely used for assessing the suitability of water for irrigation purposes. The sodium percentage $(\mathrm{Na} \%)$ is computed with respect to relative proportion of cations present in water, where the content is expressed in terms of sodium percentage or soluble sodium percentage defined as:

$$
\% \mathrm{Na}=\frac{\left(\mathrm{Na}^{+}+\mathrm{k}^{+}\right) \times 100}{\left(\mathrm{Ca}^{2+}+\mathrm{Mg}^{2+}+\mathrm{Na}^{+}+\mathrm{K}^{+}\right)}
$$

Where, all ionic concentrations are expressed in meq/l

According to the table above (table 6 ), $64.51 \%$ of the samples can be classified as permissible while $12.90 \%$ of the groundwater samples fall into the doubtful class. $22.58 \%$ of the samples fall into the unsuitable class for irrigation, meaning they have greater $\mathrm{Na}+$ levels relative to other cations in the groundwater samples.

Table 6. Classification of water based on percentage $\mathrm{Na}+$ (US salinity Laboratory, 1954)

\begin{tabular}{|c|c|c|c|}
\hline $\mathbf{N a} \%$ & Class & Number of samples & $\%$ of samples \\
\hline$<20$ & Excellent & 10 & $32.26 \%$ \\
\hline $20-40$ & Good & 6 & $19.35 \%$ \\
\hline $40-60$ & Permissible & 4 & $12.90 \%$ \\
\hline $60-80$ & Doubtful & 4 & $12.90 \%$ \\
\hline$>80$ & Unsuitable & 7 & $22.58 \%$ \\
\hline Total & & 31 & 100 \\
\hline
\end{tabular}




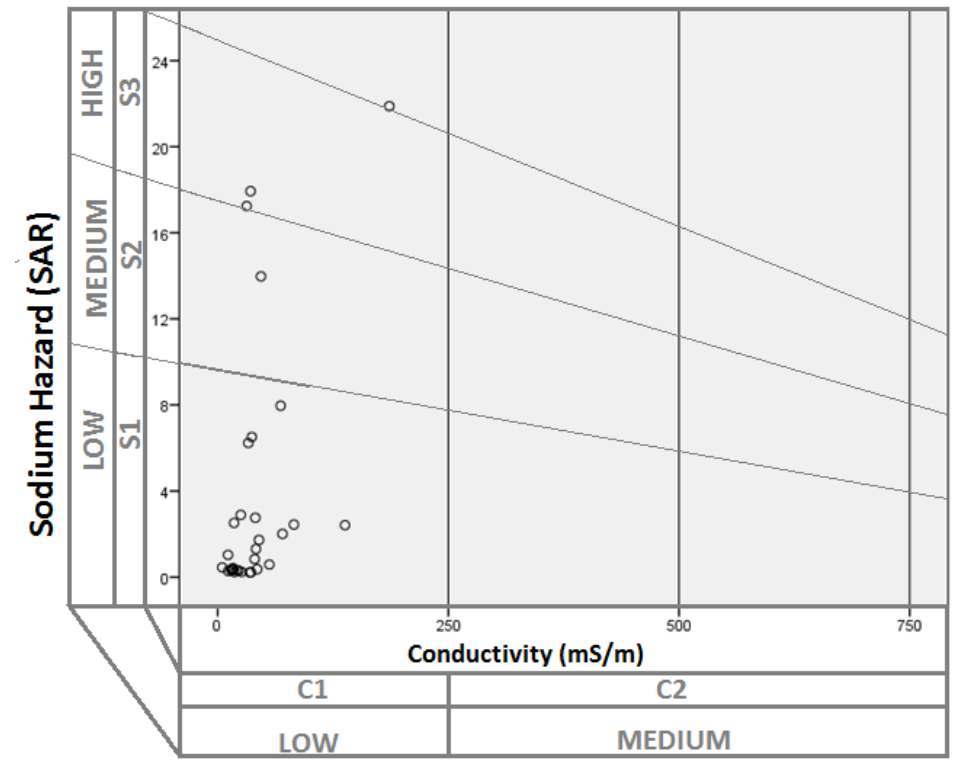

Salinity Hazard

Fig. 8. Classification of groundwater samples in relation to salinity hazard and sodium hazard

Residual Sodium Carbonate (RCS)

High RSC in irrigation water indirectly results an increase in $\mathrm{Na}+$ levels in the water which increases Sodium Hazard potential of irrigation water. RSC is calculated using the formula:

$\mathrm{RSC}=(\mathrm{HCO} 3-+\mathrm{CO} 3-)-(\mathrm{Ca} 2++\mathrm{Mg} 2+)$

(Concentrations are in $\mathrm{meq} / \mathrm{L}$ )
Table 7 shows that based on the RSC values for the samples in the study area $77.42 \%$ of the samples are safe for irrigation purposes, $16.13 \%$ fall under the marginally suitable class and only $6.45 \%$ are not suitable. This shows that the majority of the samples have higher $\mathrm{Ca} 2+$ and $\mathrm{Mg} 2+$ relative to $\mathrm{HCO} 3-$.

Table 7. RSC Classification for the study area

\begin{tabular}{|c|c|c|c|}
\hline RSC & Class & No. Of samples & \% of samples \\
\hline$<1.25$ & Safe & 24 & 77.42 \\
\hline $1.25-2.5$ & Marginally Suitable & 5 & 16.13 \\
\hline$>2.5$ & Not suitable & 2 & 6.45 \\
\hline
\end{tabular}

Kelly's Ratio. Kelly's ratio assesses irrigation water quality based on the level of $\mathrm{Na}+$ against $\mathrm{Ca} 2+$ and $\mathrm{Mg} 2+$. Kelly's ratio more than 1 indicates an excess level of $\mathrm{Na}+$ in the water and therefore the water can be considered unsuitable for irrigation. This was calculated employing the equation [11] as:

$$
\mathrm{KR}=\frac{\mathrm{Na}^{+}}{\mathrm{Ca}^{2+}+\mathrm{Mg}^{2+}}
$$

(Concentrations are in $\mathrm{meq} / \mathrm{L}$ )

The results from the computed Kelly's ratio (table 8 ) show that $35.48 \%$ of the samples in the study area are above the recommended and $64.52 \%$ of the samples are within.

Tab/e 8. Kelly's Ratio (Concentrations are in meq/L)

\begin{tabular}{|c|c|c|c|}
\hline KI & Classification & No. Of samples & \% Of Samples \\
\hline$<1$ & Suitable & 20 & 64.52 \\
\hline$>1$ & Unsuitable & 11 & 35.48 \\
\hline
\end{tabular}

Permeability index. The quality of irrigation water can affect the permeability of the soil after long term use; this can be measured by computing the Permeability index $(\mathrm{PI})$. $\mathrm{PI}$ is influenced by sodium, calcium, magnesium and bicarbonate contents of the soil. It can be classified into three classes; class I and II can be categorised as good for irrigation with $\geq 75 \%$ permeability while class III water is classified as unsuitable with $<25 \%$ of permeability [6]. PI is calculated using the formula:

$$
\mathrm{PI}=\frac{\left(\mathrm{Na}^{+}+\sqrt{\mathrm{HCO}_{3}}{ }^{-}\right) \times 100}{\mathrm{Ca}^{2+}+\mathrm{Mg}^{2+}+\mathrm{Na}^{+}}
$$

Where, all ionic concentrations are expressed in meq/l.

PI values computed for the groundwater samples for the study area ranged from 41.0 to $229,98 \%$ with mean value of $97.29 \%$. According to the classification by [6] the samples fall in the class I and class II which indicates that they are suitable for irrigation.

Magnesium hazard. The use of water with high magnesium content for irrigation may pose a threat to crop yield as it may cause alkaline condition in the soil. [13] developed an index for calculating the magnesium hazard (magnesium ratio (MR). MR is calculated using the formula:

$$
\mathrm{MR}=\frac{\mathrm{Mg}^{2+} \times 100}{\mathrm{Mg}^{2+}+\mathrm{Ca}^{2+}}
$$

Where, all ionic concentrations are expressed in meq/l.

The computed MR values for the study area range between 15.48 to $72.14 \%$ with mean value of $40.35 \%$. Less than $50 \%$ of MR is suitable for irrigation while more than $50 \% \mathrm{MR}$ is unsuitable for irrigation practice. The results show that $74.19 \%$ of the samples from the study area are suitable for irrigation and $22.80 \%$ are unsuitable 
with respect to MR. This indicates that $22.80 \%$ of the groundwater samples have a potential to cause alkaline soil which is known to have low infiltration capacity.

Conclusions. The aim of this study was to evaluate the quality of groundwater in Newcastle and to determine the suitability of the water for drinking and irrigation purposes. The SAWQG [5] and [19] water guidelines were used as the basis of evaluating the groundwater for drinking purposes. For irrigation, EC (salinity hazard), Sodium percent, Sodium Adsorption Ratio (SAR), Residual Sodium Carbonate (RSC), Kelly's ratio (KR), Magnesium hazard and Permeability index were used. The spatial distribution of these results was presented using ArcGIS.

Most of the samples were found to be within the permissible range for both the SAWQG [5] and [19] water guidelines, with only a few falling outside target/permitted range. The groundwater was found to be alkaline in nature with only one sample with $\mathrm{pH}$ above the target water range. About $12.90 \%$ of the samples have Ec levels above the SAWQG (DWAF, 1996) target water range and $16.13 \%$ of the samples showed higher levels of TDS. While most of the samples presented concentrations within the desirable range, a few showed concentration of $\mathrm{Na}+, \mathrm{Cl}-$, SO42-, F- and TDS above the guideline value as per [19] standards The dominance of major ions in the area is as $\mathrm{Na}+>\mathrm{Ca} 2+>\mathrm{Mg} 2+>\mathrm{K}+$ and $\mathrm{HCO} 3->\mathrm{Cl}->\mathrm{SO} 42+>\mathrm{NO} 3-$

According to the classification based on TDS by [3] none of the samples in the study area are unfit for drinking and irrigation purposes and the Freeze and Cherry classification based on TDS classifies $93.54 \%$ of the samples as freshwater and $6.45 \%$ as brackish [18]. Classification based on $\mathrm{TH}$ classifies $22.58 \%$ of the samples as hard and $3.23 \%$ as very hard.

Assessments for irrigation showed that all of the samples fall into the low salinity hazard category according to the classification base on Ec by [19]. Based on the SAR and Permeability index all the samples were found suitable for irrigation while the $\mathrm{Na} \%$, RSC, Kelly's ratio and Magnesium Ratio showed that the water from boreholes and catchments 1;V31J, 3;V31D, 4;V31C, 5;V31J, 6,V31J, 9;V31C, 11;V31B, 12;V31A, 13;V32B, 14;V31D, 21;V31B, 22;V31D, 23;V31K, $25 ; \mathrm{V} 31 \mathrm{~F}$ respectively, are unsuitable for irrigation because of its potential to causes sodium hazard.

Recommendations. In view of the findings, it is recommend that the water in the boreholes that exceeded the [19] guidelines and in the boreholes that showed high sodium hazard potential should be treated before use. In future studies, more parameters should be analyzed and observed, such as heavy/trace metals and organics (pesticides and pharmaceuticals) and the effects of seasonal changes or influences in groundwater should be monitored. Programs should also be implemented on how to better protect groundwater from anthropogenic impacts.

Список використаних джерел

1. Abudaya M. Assessment of Chemical Characteristics of the Desalinated Water Used in Household Facilities in Gaza Strip / M. Abudaya, A.Tayeh, A. EL Ramlawi // Journal of Natural Sciences Research. - 2014. Vol. 4, № 1. - P. 72-83.

2. Catuneanu $O$. The Karoo basins of south-central Africa / O. Catuneanu, H. Wopfner, P. Eriksson et al. // Journal of African Earth Sciences. - 2005. - Vol. 43, № 1. - P. 211-253.

3. Davis S. Hydrogeology / S. Davis, R. De Wiest. - New York: John Wiley \& Sons, 1966. - Vol. 463.

4. Department Water Affairs and Forestry (DWAF). KwaZulu-Natal Groundwater Plan, Version 2, 2008.

5. Department of Water Affairs and Forestry (DWAF): in Holmes S. (Ed.). South African water quality guidelines (2nd ed.), 1996. - Vol. 1.

6. Doneen, L.D. Notes on water quality in agriculture. / L.D. Doneen; Department of Water Science and Engineering Paper 4001. - University of California, Davis, 1964

7. Elamassi K.S. Assessment of groundwater quality using multivariate and spatial analyses in Gaza governorate-Palestine. / K.S. Elamassi; The Islamic University-Gaza, 2012. - 106 p.
8. Freez, R.A. .Groundwater. / R.A. Freez, J.A. Cherry. - New Jersey: Prentice Hall Inc., 1979

9. Hem J.D. Study and interpretation of the chemical characteristics of natural water. / J.D. Hem; US Geological Survey Water-Supply, 3rd edn. - Scientific Public, Jodhpur, 1991.

10. Hiscock K. Hydrogeology: principles and practice / K. Hiscock. John Wiley \& Sons, 2009

11. Kelly W.P. Use of Saline Irrigation Water. / W.P. Kelly // Soil Sci. 1963. - Vol. 95(4). - P. 355-391

12. Nolakana P. Geochemical evaluation of groundwater quality in Newcastle, KwaZulu-Natal, South Africa. / P. Nolakana, A. Siad, $\mathrm{H}$. Solomon // Visnyk of Taras Shevchenko National University of Kyiv: Geology. - 2016. - Vol. 4 (74). - P. 68-76.

13. Paliwal K.V. Irrigation with saline water. / K.V. Paliwal; Water Technology Centre, Indian Agricultural Research Institute New Delhi, 1972.

14. Peacock L.W. Interpretation of Soil and Water Analysis I L.P. Christensen. - Raisin production manual, ed. L.P. Christensen, UCANR Publications, 2000. - P. 115

15. Raju N.J. Hydrogeochemical parameters for assessment of groundwater quality in the upper Gunjanaeru River basin, Cuddapah District, Andhra Pradesh, South India / N.J. Raju // Environmental Geology. - 2007. - Vol. 52, № 6. - P. 1067-1074.

16. Ramesh K. Groundwater quality and its suitability for domestic and agricultural use in Tondiar river basin, Tamil Nadu, India / K Ramesh, L. Elango // Environmental monitoring and assessment. - 2012. - Vol. 184 № 6. - P. 3887-3899.

17. Sawyer C.N. Chemistry for sanitary engineers / C.N. Sawyer, P.L. McCarty; (2nd ed.). - New York: Education, McGraw-Hill, 1967.

18. US Salinity Laboratory Staff. Diagnosis and improvement of saline and alkali soils. - USDA, Handbook 60, U.S. Government Printing Office, Washington D.C., 1954

19. World Health Organization (WHO). Guidelines for drinking-water quality (4thed.). - WHO Library Cataloguing-in-Publication Data, 2011. $564 \mathrm{p}$.

20. World Health Organization (WHO). Guidelines for drinking-water quality (3rded.). - Geneva: World Health Organization, 2008

\section{References}

1. Abudaya, M., Tayeh, A., EL Ramlawi, A. (2014). Assessment of Chemical Characteristics of the Desalinated Water Used in Household Facilities in Gaza Strip. Journal of Natural Sciences Research, 4, 1, 72-83.

2. Catuneanu, O., Wopfner, H., Eriksson, P., Cairncross, B., Rubidge, B., Smith, R., Hancox, P. (2005). The Karoo basins of south-central Africa. Journal of African Earth Sciences, 43, 1, 211-253.

3. Davis, S., De Wiest, R. (1966). Hydrogeology. New York: John Wiley \& Sons, Vol. 463

4. Department Water Affairs and Forestry (DWAF). (2008). KwaZuluNatal Groundwater Plan, Version 2

5. Department of Water Affairs and Forestry (DWAF). (1996). In Holmes S. (Ed.), South African water quality guidelines (2nd ed.), Vol. 1: Domestic Use. Pretoria: Department of Water Affairs and Forestry.

6. Doneen, L.D. (1964). Notes on water quality in agriculture. Department of Water Science and Engineering Paper 4001. University of California, Davis.

7. Elamassi, K.S. (2012). Assessment of groundwater quality using multivariate and spatial analyses in Gaza governorate-Palestine. The Islamic University-Gaza, $106 \mathrm{p}$.

8. Freez, R.A., Cherry, J.A. (1979).Groundwater. New Jersey: Prentice Hall Inc.

9. Hem JD (1991). Study and interpretation of the chemical characteristics of natural water. US Geological Survey Water-Supply, 3rd edn, Scientific Public, Jodhpur.

10. Hiscock, K. 2009, Hydrogeology: principles and practice. John Wiley \& Sons

11. Kelly, W.P. (1963). Use of Saline Irrigation Water. Soil Sci. 95(4), 355-391.

12. Nolakana, P Siad, A, Solomon, H. (2016). Geochemical evaluation of groundwater quality in Newcastle, KwaZulu-Natal, South Africa. Visnyk of Taras Shevchenko National University of Kyiv: Geology, 4(74), 68-76.

13. Paliwal, K.V. (1972). Irrigation with saline water. Water Technology Centre, Indian Agricultural Research Institute New Delhi.

14. Peacock, L.W., Christensen, L.P. (2000). Interpretation of Soil and Water Analysis. Raisin production manual, ed. L.P. Christensen, UCANR Publications, 115.

15. Raju, N.J. (2007). Hydrogeochemical parameters for assessment of groundwater quality in the upper Gunjanaeru River basin, Cuddapah District, Andhra Pradesh, South India. Environmental Geology, 52, 6, 1067-1074.

16. Ramesh, K., Elango, L. (2012). Groundwater quality and its suitability for domestic and agricultural use in Tondiar river basin, Tamil Nadu, India. Environmental monitoring and assessment, 184, 6, 3887-3899.

17. Sawyer, C.N., McCarty, P.L. (1967).Chemistry for sanitary engineers (2nd ed.).New York: Education, McGraw-Hill.

18. US Salinity Laboratory Staff. (1954). Diagnosis and improvement of saline and alkali soils. USDA, Handbook 60, U.S. Government Printing Office, Washington D.C

19. World Health Organization (WHO). (2011). Guidelines for drinkingwater quality (4thed.). WHO Library Cataloguing-in-Publication Data, 564 p.

20. World Health Organization (WHO). (2008). Guidelines for drinkingwater quality (3rded.). Geneva: World Health Organization. 
Памела Нолакана, Абді Сіад, Хенок Соломон

Кафедра Наук про Землю, Факультет Наук, Університет Західного Кейпу, Прайвет Бег X 17

Модердам Роуд, Бельвіль, 7535, Кейптаун, Південна Африка

\section{ОЦІНКА ПРИДАТНОСТІ ПІДЗЕМНИХ ВОД ДЛЯ ПОБУТОВОГО ВЖИТКУ ТА ПОЛИВУ У НЬЮКАСЛІ, КВАЗУЛУ-НАТАЛ, ПІВДЕННА АФРИКА}

Дослідження проводилися у Ньюкаслі, провінція Квазулу-Натал, Південна Африка. 3 метою визначення якості підземних вод у межах території дослідження було відібрано 31 зразок. Зразки аналізувалися на вміст магнію (Mg2+), кальцію (Cа2+), натрію (Na+), калію $(\mathrm{K}+)$, хлору (Cl-), сульфатів (SO42-), бікарбонатів (HCO3-), нітратів (NO3-), фтору (F-), а також рH. Cтандарти Південної Африки щодо якості води (SAQWG), а також стандарти, які запроваджує Всесвітня Організація Охорони Здоров'я ВОз (WHO) використовувалися у якості основи для визначення можливості вжитку підземних вод для пиття. Для оцінки придатності для поливу використовувалися електрична провідність (EC), вміст у відсотках натрію (Na \%), адсорбційне відношення натрію (SAR), залишковий карбонат натрію (RSC), відношення Келі (KR), відношення магнію (MR) та індекс проникності (PI). Просторовий розподіл результатів наводиться із використанням ArcGIS. Підземні води охарактеризовано у більшості випадків як лужні, м'які та жорсткі, солонуваті у природному стані. На основі визначення середніх значень отримано такий порядок вмісту основних іонів у підземних водах $\mathrm{Na}+>\mathrm{Ca2+>Mg2+>K+} \mathrm{and} \mathrm{HCO3-}$ $>\mathrm{SO} 42->\mathrm{Cl}->\mathrm{NO} 3$

Ключові слова: підземні води, SAQWG, придатність, побутовий вжиток, зрошення.

Памела Нолакана, Абди Сиад, Хенок Соломон

Кафедра Наук о Земле, Факультет Наук, Университет Западного Кейпа, Прайвет Бег X 17

Моддердам Роад, Бельвиль, Кейптаун, Южная Африка

\section{ОЦЕНКА ПРИГОДНОСТИ ПОДЗЕМНЫХ ВОД ДЛЯ БЫТОВОГО ПОТРЕБЛЕНИЯ И ПОЛИВА В НЬЮКАСЛЕ, КВАЗУЛУ-НАТАЛ, ЮЖНАЯ АФРИКА}

Исследования проводились в Ньюкасле, провинция Квазулу-Натал, Южная Африка. С целью определения качества подземных вод в пределах территории исследования был отобран 31 образец. Образцы анализировались на содержание магния (Мg2+), кальция (Са2+), натрия (Na+), калия (K+), хлора (Cl-), сульфатов (SO42-), бикарбонатов (HCO3-), нитратов (NO3-), фотора ( F-), а также pH. Cтандарть Южной Африки по качеству воды (SAQWG), а также стандарты, которые использует Всемирная Организация Здравохранения ВОз (WHO) применялись в качестве основы для определения возможности потребления подземных вод для питья. Для оценки пригодности для полива использовались электрическая проводимость (EC), содержание в процентах натрия (Na \%), адсорбционное отношение натрия (SAR), остаточный карбонат натрия (RSC), отношение Келли (KR), отношение магния (MR) и индекс проницаемости (PI). Пространственное распределение результатов приводится с использованием ArcGIS. Подземные воды охарактеризованы в большинстве случаев как щелочные, мягкие и жесткие, солоноватые в естественном состоянии. На основе определения средних значений получен такой порядок содержания основных ионов в подземных водах $\mathrm{Na}+>\mathrm{Ca} 2+>\mathrm{Mg} 2+>\mathrm{K}+$ and $\mathrm{HCO}->\mathrm{SO} 42->\mathrm{Cl}->\mathrm{NO} 3-$

Ключевые слова: подземные воды, SAQWG, пригодность, бытовое потребление, орошения. 